\title{
Oppimisvaikeudet työelämässä
}

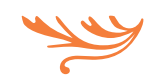

\begin{abstract}
Suomalaisista aikuisista noin kymmenesosalla on lukutaidossaan ongelmia, jotka vaikeuttavat oppimista, työllistymistä ja työntekoa. Oppimisvaikeuksien huomioimista työpaikoilla on tutkittu Suomessa, Ruotsissa, Norjassa ja Islannissa. Tulosten mukaan oppimisvaikeuksia ei huomioida työhön perehdyttämisessä tai luottamusmies- ja työsuojelukoulutuksessa missään Pohjoismaissa.
\end{abstract}

OpPIMISVAIKEUKSISTA kärsivien tukemiseksi, auttamiseksi ja edunvalvontatyöhön perustetun Erilaisten oppijoiden liiton mukaan 20-25 prosentilla väestöstä eli miljoonalla suomalaisella on jonkinlaisia oppimisvaikeuksia. Arvioon on luettu mukaan kaikenlaiset oppimisvaikeudet - lievät ja vaikeat. Eri tutkimusten tuottamat arviot väestön luku- ja kirjoitusvaikeuksisten osuudesta vaihtelevat 3-10 prosentin välillä.

Pulmia voi olla paitsi lukemisessa ja kirjoittamisessa sinänsä myös kuuntelemisessa, luetun ymmärtämisessä, muistamisessa ja päättelyssä. Lukivaikeuksinen saattaa lukea teknisesti verraten nopeastikin, mutta hänellä "ei jää mitään päähän”. Lukivaikeudet haittaavat vieraiden kielten oppimista. Myös avaruu- dellinen ja ajan hahmottaminen voi olla vaikeaa. Niin ikään suuntien hahmottaminen (oikea-vasen, itä-länsi) tuottaa vaikeuksia. Monilla on hankaluuksia keskittymisessä ja tarkkaavaisuudessa.

Kehityksellisten oppimisvaikeuksien uskotaan johtuvan keskushermoston erilaisesta toiminnasta, ja ne saattavat ilmetä läpi ihmisen elämänkaaren. Lukivaikeuteen yhdistyvät usein matematiikan oppimisvaikeudet. Matemaattisen hahmottamisen vaikeutta ilman lukivaikeutta on $2-3$ prosentilla väestöstä.

\section{Luku- ja numerotaidon riskiryhmät}

Vuonna 2012 suoritettujen aikuisten oppimista mittaavien PIAAC-testien mukaan testeihin osal- 


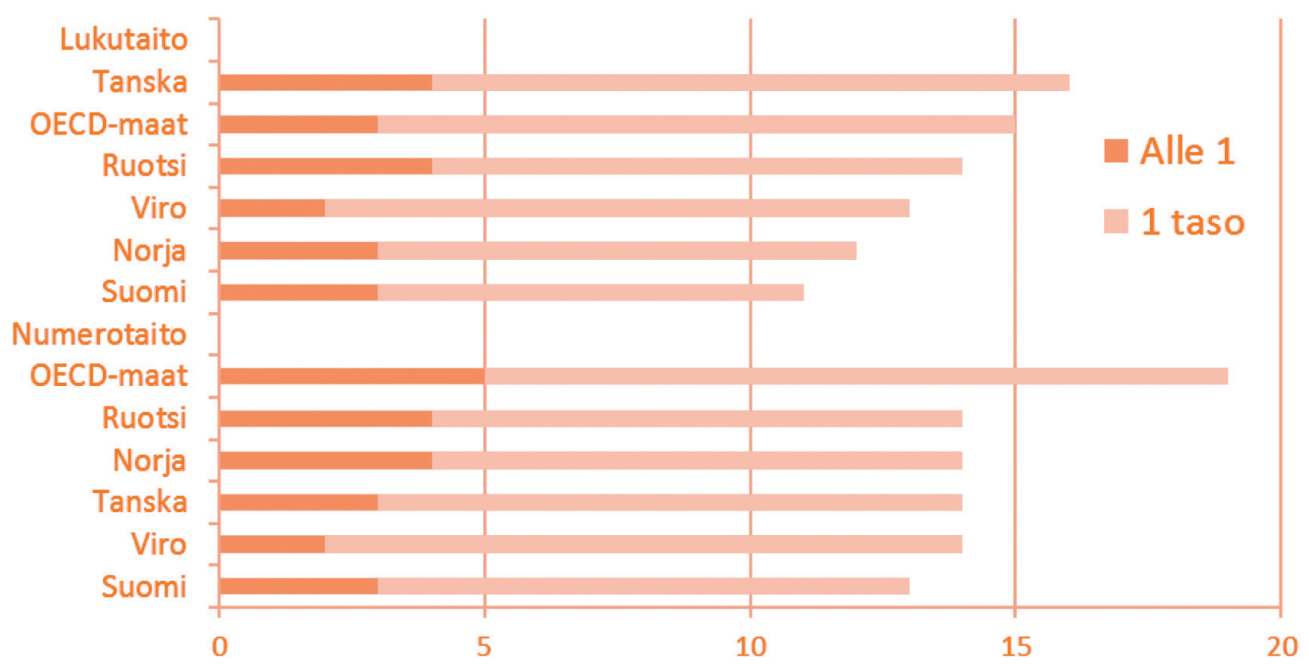

Kuvio 1. Luku- ja numerotaidoiltaan heikkojen aikuisten osuus Norjassa, Ruotsissa, Suomessa, Tanskassa, Virossa sekä OECD-maissa keskimäärin: PIAAC-testissä alle tason 1 jäävien ja tasolle 1 yltävien osuus (\%).

Lähde: Malin ym. 2014, 19, 23.

listuneissa OECD-maissa 15 prosentilla aikuisista on huono lukutaito ja 19 prosentilla huonot numerotaidot. Suomessa heikkojen lukijoiden osuus on pienempi kuin muissa Pohjoismaissa. Suomalaisista aikuisista noin kymmenesosalla on lukutaidossaan sellaisia vaikeuksia, jotka vaikeuttavat oppimista, työllistymistä ja työntekoa. Heikko lukutaito rajoittaa arkielämää ja harrastuksia sekä vähentää opiskeluhaluja ja aikuisopiskelua.

Heikot numerotaidot on 14 prosentilla suomalaisista. Pohjoismaissa (ja Virossa) heikkojen laskijoiden osuus on selvästi pienempi kuin OECD-maissa keskimäärin. Pohjoismaiden välillä ei ole eroja. Vuoden 1998 IALS-mittaukseen (International Adult Literacy Survey) verrattuna lukutaidoltaan heikkojen aikuisten osuus on pysynyt Suomessa samansuuruisena (Linnakylä ym. 2000; Malin 2006; Malin ym. 2014, 20).

Kun PIAACin paljastamat väestöosuudet muunnetaan lukumääriksi, saadaan jonkinlainen käsitys siitä, kuinka suuresta joukosta suomalaisia on kysymys (taulukko 1.) Lukutaidon "riskiryhmään” lukeutuu noin 370000 suomalaista aikuista. Heikoilla numerotaidoilla varustettuja aikuisia on Suomessa lähes puoli miljoonaa. Ongelmanratkaisutaidoiltaan heikkoja on noin 385 000. Kaikilla osaamisalueilla heikoiksi luokittuvia on noin satatuhatta. Kaikissa riskiryhmissä keski-ikä on väestön keskiarvoa selvästi korkeampi.

PIAAC-testeissä heikosti menestyneet eivät suinkaan kaikki luokitu tai diagnosoidu oppimisvaikeuksisiksi. Koe- ja testitilanteet ovat kuitenkin monille vaikeita, mikä on omiaan vaikuttamaan suoritustasoa heikentävästi. Tämä on todettu muun muassa hitautena, hätiköintinä ja keskittymisvaikeuksina ylioppilaskirjoituksissa ja pääsykokeissa.

Kun työelämän kognitiiviset vaatimukset kasvavat ja monimuotoistuvat, oppimisvaikeuksien vaikutukset kärjistyvät. Oppimisvaikeuden kanssa selviytymistä kuvaavassa tutkimuksessa haasta- 


\begin{tabular}{|l|ccc|}
\hline PERUSTAITO & OSUUS AIKUISVÄESTÖSSÄ (\%) & LUKUMÄÄRÄ & KESKI-IKÄ (X) \\
\hline Lukutaito & 10,6 & 370000 & 49 \\
Numerotaito & 12,8 & 450000 & 47 \\
Ongelmanratkaisutaito* & 11,0 & 385000 & 50 \\
Luku- ja numerotaito & 8,1 & 280000 & \\
Luku-, numero- ja & & 100000 & \\
ongelmanratkaisutaito & 2,7 & \\
\hline
\end{tabular}

Taulukko 1. Perustaidoiltaan heikkotasoisten (suoriutuivat PIAAC-testissä korkeintaan tasolle 1) aikuisten osuus ja lukumäärä Suomessa.

Lähde: Malin ym. 2014, 78, 92.

* Ongelmanratkaisutaidon riskiryhmässä eivät ole mukana henkilöt, jotka eivät tehneet tietotekniikkaa soveltavia ongelmanratkaisutehtäviä. Suomessa heitä oli 18,6 \% tutkimukseen osallistuneista. Todennäköisesti ongelmanratkaisutaidon riskiryhmä on siis taulukon lukua suurempi.

tellut itse toivat esille sen, että tuki ja ohjaus olisi erityisen tärkeää opintojen nivelvaiheissa ja työelämän muutostilanteissa (Korkeamäki 2010). Ja mitä korkeammalla koulutusasteella opiskellaan, sitä tärkeämpää on nopea lukeminen ja tekstin prosessointi. Työmuistin ja kielellisen muistin rajoitukset ilmenevät usein oppimisvaikeuksien seuralaisena. Ne hidastavat oppimisprosessia. Mieleen painaminen ja ulkoa opettelu vievät paljon aikaa ja edellyttävät runsaasti kertaamista. Kirjallisten taitojen hitauden ja aikataulujen hallintavaikeuksien vuoksi työt ja opinnot viivästyvät. Tehtävien kasautuminen puolestaan johtavat pahimmillaan ylikuormittumiseen, uupumukseen ja masennukseen. (Reiterä-Paajanen \& Haapasalo 2010, 14.)

Oppimisvaikeuksien kanssa kamppailevien selviytymistä työssä on kuitenkin mahdollista helpottaa ottamalla asia tietoisemmin esille työpaikoilla. Osalla oppimisvaikeudet on tunnistettu jo kouluaikana ja yhä useammalla jo ennen sitä. Mutta kun tukitoimet jäävät lapsuudessa vähäisiksi, ongelmat kasautuvat aikuisena. Osalla vaikeudet tunnistetaan vasta aikuisiällä, jolloin oppimisvaikeudet ovat jo sisäistyneet "huonoksi matikkapääksi" tai "huonoksi kielipääksi”. Vanhimmissa ikäryhmissä oppimisvai- keuksia pidetään alitunnistamattomina ja alihoidettuina. (Ks. esim. Gerber ym. 1990.)

\section{OPPIMISVAIKEUDET HAITTAAVAT TYÖELÄMÄSSÄ}

Johanna Korkeamäki kirjoitti vuonna 2011 Aikuiskasvatus-lehdessä oppimisvaikeuksista kärsivien aikuisten tukitarpeista. Hän totesi oppimisvaikeuksien yhdistyvän monenlaisiin sosiaalisiin ongelmiin. Tutkimuksissa on raportoitu jatko-opiskelumahdollisuuksien kaventumisesta, keskimääräistä matalammasta koulutustasosta ja muuta väestöä korkeammasta työttömyydestä. Oppimisvaikeuksien yhteydessä esiintyy usein erilaisia itsetunto- ja mielenterveysongelmia - erityisesti naisilla. Oppimisvaikeuksien vaikutusten on myös arvioitu lisääntyvän työelämän vaatimusten kasvaessa.

Korkeamäen kyselytutkimuksen mukaan aikuiset, joilla on oppimisvaikeuksia, kokevat vaikeuksien häiritsevän itseään eniten työssä, tiettyjen aineiden opinnoissa ja yleisissä opiskelutaidoissa. Työssäkäyvistä kolme neljästä kokee oppimisvaikeuden häiritsevän tiettyjä työtehtäviä.

Tyypillisiä vaikeuksia työelämässä ovat vieraiden kielten ja vierasperäisten termien käyttöön liittyvät hankaluudet, työssä koetut keskeytykset ja 
lukemisen ja kirjoittamisen työläys. Myös aiemmissa tutkimuksissa on todettu, että Suomessa monet kokevat oppimisvaikeuksien yhteydessä suurimpia vaikeuksia vieraissa kielissä. Ikääntyminen vaikuttaa siihen, miten häiritsevinä oppimisvaikeudet koetaan: oppimisvaikeus häiritsee työssä selviytymistä, työnhakua ja arjen asioita sitä enemmän, mitä vanhempi ihminen on. (Korkeamäki 2011.)

Kirjallisiin töihin tai uusien tehtävien perehdyttämiseen töissä ei ole varattu riittävästi aikaa. Työpaikan palavereissa vaikeuksia voivat tuottaa puheen seuraaminen sekä kokouspöytäkirjan pitäminen. Myös opiskeluissa vaikeuksia tuottavat tyypillisimmin vieraiden kielten opinnot. Lisäksi hankaluuksia aiheuttavat muistiinpanojen tekeminen, luettavan materiaalin laajuus ja vaikeaselkoisuus sekä opinnäytetyöt. Arjen hankaluuksia ovat esimerkiksi erilaiset lomakkeet ja vaikkapa lääkelaskut. (Korkeamäki 2010; 2011; Korkeamäki, Reuter \& Haapasalo 2010.)

\section{OPPIMISVAIKEUKSIEN HUOMIOIMINEN TYÖPAIKOILLA}

Tammikuussa 2015 julkaistussa Oppimisvaikeudet työpaikoilla -tutkimuksessa luottamusmiehet, työsuojeluvaltuutetut ja työnantajan edustajat kertovat kokemuksiaan ja näkemyksiän oppimisvaikeuksista työpaikoilla sekä siitä, miten niistä selviytymistä tuetaan. Pohjoismaiden ministerineuvoston Nordplus Aikuiskoulutus -ohjelman tukeman tutkimuksen aineisto kerättiin sähköisen kyselyn avulla Suomessa, Ruotsissa, Norjassa ja Islannissa yhteistyössä kunkin maan ammattiliittojen kanssa.

Kysely toteutettiin kussakin maassa neljässä ammattiliitossa ja suunnattiin näiden liittojen luottamusmiehille ja työsuojeluvaltuutetuille. Näitä pyydettiin valitsemaan työpaikaltaan joku työnantajan edustaja, jolle pyydettiin välittämään saatekirje vastaamisosoitteineen. Vastauksia kertyi kaikkiaan 703. Suurin aineisto saatiin Suomesta: 433 vastausta. Vähiten vastaajia on Islannista: 39 vastausta. Ruotsista vastaajia on 107 ja Norjasta 124. Ylei- simmin vastaajana oli luottamusmies. Työsuojeluvaltuutettuja vastasi eniten Suomesta ja Ruotsista. (Puumalainen ym. 2015.)

Kyselyyn vastanneiden käsityksiä kuvaavana tulokset ovat ainakin suuntaa antavia. Suomen osalta tutkimusta voidaan sanoa muita osallistujamaita kattavammaksi. Suomesta mukana on vastaajia melko monipuolisesti teollisuudesta, palvelualoilta, julkisen sektorin puolelta sekä suurista ja pienistä yrityksistä, naisvaltaisista ja miesvaltaisista työpaikoista ja henkilöstön keski-iältä erilaisista työpaikoista. Suomen aineistoa voi pitää kohtuullisen hyvänä tutkimustarkoituksiin.

Suurimmalle osalle luottamusmiehistä, työsuojeluvaltuutetuista ja työnantajan edustajista oppimisvaikeudet ovat tuttu asia (kuvio 2). Muissa Pohjoismaissa oppimisvaikeudet tunnetaan työelämässä ehkä hieman paremmin kuin Suomessa. Muissa maissa 93 \% vastaajista pitää oppimisvaikeuksia tuttuna asiana, kun Suomessa osuus on $77 \%$. Yli puolet vastaajista tiesi työpaikallaan olevan henkilöitä, joilla heidän mukaansa oli oppimisvaikeuksia. Suomalaiset vastaajat olivat kiinnittäneet muita maita useammin huomiota tarkkaavaisuuden ongelmiin sekä uuden oppimisen hankaluuteen, muiden maiden vastaajat puolestaan olivat useimmin kiinnittäneet huomiota kirjoittamiseen liittyviin ongelmiin. Yksityisellä sektorilla oppimisvaikeuksia huomattiin herkemmin kuin julkisen sektorin työpaikoilla ja suuremmilla työpaikoilla useammin kuin pienemmillä. (Puumalainen ym. 2015.)

Suomalaisvastaajista reilu kolmasosa toteaa, että joku on ottanut heidän kanssaan puheeksi joko omat tai työtoverinsa oppimisvaikeudet. Muissa Pohjoismaissa omista tai työtoverin oppimisvaikeuksista puhuminen työpaikalla yksityisesti on selvästi harvinaisempaa kuin Suomessa. Sen sijaan varsin harvalla työpaikalla puhutaan oppimisvaikeuksista virallisemmin koko henkilöstön kanssa. Peräti 90 \% suomalaisista luottamusmiehistä, työsuojeluvaltuutetuista ja työnantajan edustajista toteaa, ettei heidän työyhteisössään ole puhuttu oppimis- 


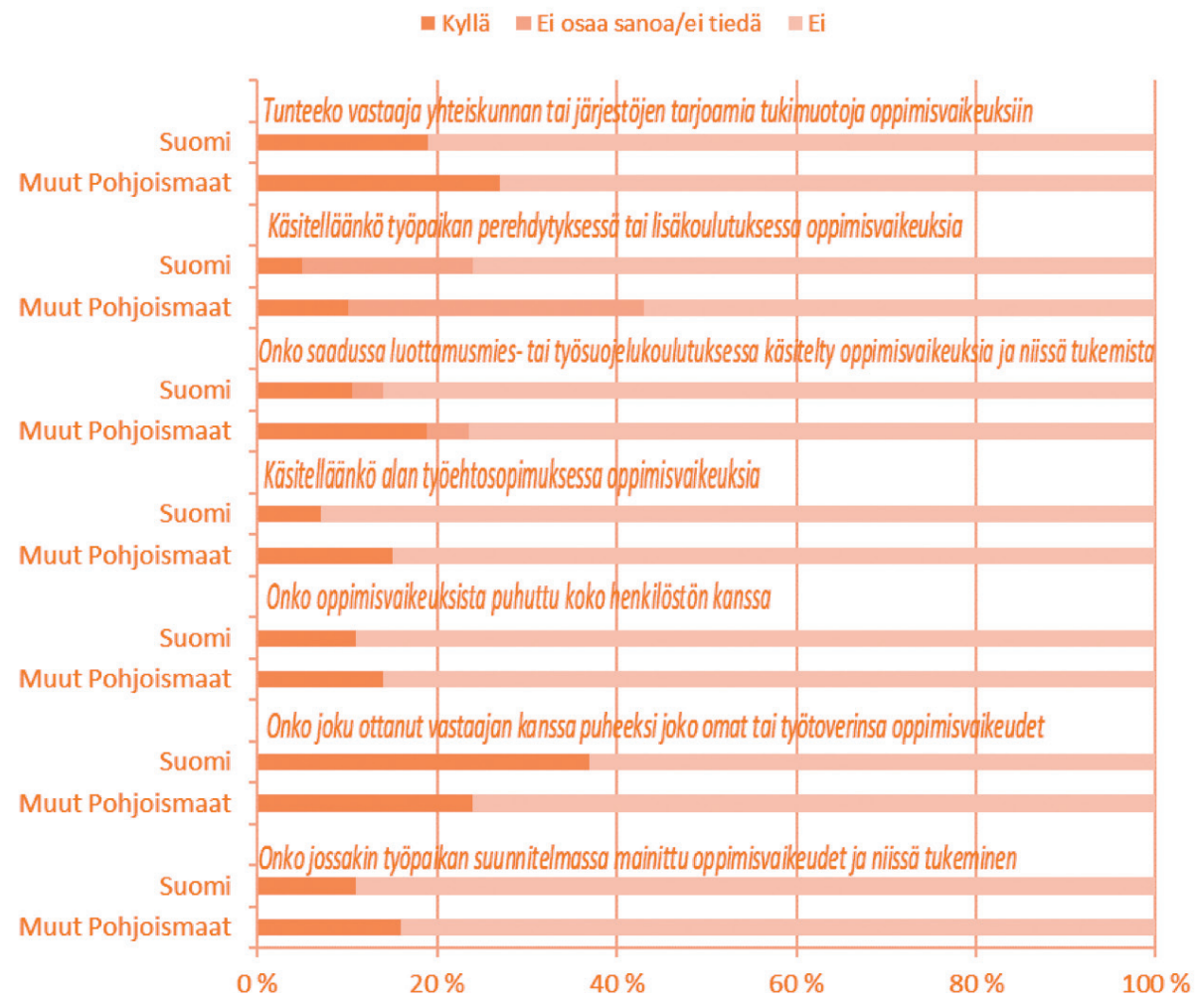

Kuvio 2. Luottamusmiesten, työsuojeluvaltuutettujen ja työnantajan edustajien käsitykset siitä, miten työelämässä käsitellään oppimisvaikeuksia Suomessa ja muissa Pohjoismaissa (\%).

Lähde: Puumalainen 2015.

vaikeuksista koko henkilöstön kesken. Muissa Pohjoismaissa puhuminen koko henkilöstön on hiukan yleisempää.

Tulosten mukaan oppimisvaikeuksia käsitellään perehdytyksessä tai lisäkoulutuksessa aika harvalla työpaikalla. Suomessa oppimisvaikeuksien käsittely työpaikalla on harvinaisempaa kuin muissa Pohjoismaissa. Vain viisi prosenttia suomalaisista on sitä mieltä, että oppimisvaikeuksia käsitellään perehdytyksessä tai lisäkoulutuksessa, ja lähes neljä viidestä on sitä mieltä, että asiaa ei käsitellä. Se on selvästi suurempi osuus kuin muissa Pohjoismaissa.

Kun luottamusmiehiltä ja työsuojeluvaltuutetuilta kysyttiin, onko heidän koulutuksessaan kä- sitelty oppimisvaikeuksia ja niissä tukemista, vain noin joka kymmenes vastaaja totesi saamassaan koulutuksessa käsitellyn asiaa. Suomessa $74 \%$ luottamusmiehistä ja työsuojeluvaltuutetuista totesi, ettei heidän koulutukseensa ole sisältynyt oppimisvaikeuksien käsittelyä. Muissa Pohjoismaissa oppimisvaikeuksista puhuminen luottamusmiestai työsuojelukoulutuksessa on yleisempää, mutta missään tutkimukseen kuuluneessa maassa se ei näytä olevan tavanomaista.

Suomalaisista vain $7 \%$ toteaa, että oppimisvaikeuksia käsitellään alan työehtosopimuksissa. Muissa Pohjoismaissa osuus on selvästi suurempi, vaikkakaan ei silti kovin suuri. Työsuojeluvaltuutettujen 
käsityksen mukaan oppimisvaikeuksien esille ottaminen alan työehtosopimuksessa on yleisempää kuin muiden kyselyyn vastanneiden mukaan.

\section{TUKEMINEN TYÖELÄMÄSSÄ}

Oppimisvaikeuksien tunnistamisen ohella erityisen tärkeä aihe on oppimisvaikeuksien käsitteleminen työpaikoilla: miten erilaisuutta suvaitaan ja miten erilaisia oppijoita koetetaan auttaa ja tukea. Suomessa viidesosa ja muissa Pohjoismaissa neljäsosa vastaajista sanoo tuntevansa yhteiskunnan tai järjestöjen tarjoamia tukimuotoa oppimisvaikeuksiin (kuvio 2). Kyselyssä työnantajapuolta edustaneet vastaajat totesivat muita useammin tietävänsä, mistä oppimisvaikeuksiin saa tukea ja neuvoja.

Suomessa näyttää olevan muita Pohjoismaita yleisempää, että työpaikoilla työtehtäviä jaetaan työntekijöiden taitojen ja taipumusten eli vahvuuksien mukaan, mikä voi olennaisesti vaikuttaa siihen, miten oppimisvaikeudet vaikuttavat työssä suoriutumiseen. Suomessa on lisäksi muita verrokkimaita tavallisempaa sopia työtoverien auttamisesta hankalissa työvaiheissa. (Taulukko 2.) Huolelliseen perehdyttämiseen näytetään suomalaisessa työelämässä kiinnitettävän selvästi enemmän huomiota kuin muissa Pohjoismaissa. Suomalaisvastaajista noin neljännes sanoo omalla työpaikallaan panostettavan huolelliseen ohjeistukseen ja perehdyttämiseen. Muiden Pohjoismaiden ryhmässä vastaava osuus on vain muutama prosentti.

Noin kymmenesosa kyselyyn vastanneista sanoo, että työpaikalla järjestetään lisäaikaa työtehtävien tekemiseen. Erillisiä, rauhoitettuja työtiloja oppimisvaikeuksisille sen sijaan järjestetään hyvin harvoin.

\section{OPPIMISVAIKEUKSIEN DIAGNOSOINNISTA}

Peruskoulussa oppimisvaikeuksien arviointi perustuu opettajan tekemään pedagogiseen arvioon, eikä tuen saaminen edellytä lääketieteellistä diagnoosia. Aikuisten oppimisvaikeuksien arviointi on perustunut pitkälti vain testaajien omaan ammattitaitoon asiassa, eikä käytössä ole yhdenmukaisia ja psykometrisesti luotettavia testejä. Oppimisvaikeuksien määrittämiseen osallistuu muitakin kuin perinteisiä lääketieteen edustajia. Oppimisvaikeuden voi todeta psykologi, erityisopettaja tai puheterapeutti, mutta virallisen diagnoosin antaa Suomessa aina lääkäri muiden ammattilaisten tutkimusten perusteella. Lääkärin diagnoosi tarvitaan esimerkiksi ylioppilastutkinnon erityisjärjestelyjen ja joidenkin muiden etuuksien saamiseksi. Läääri on myös keskei-

\begin{tabular}{|c|c|c|c|c|}
\hline TUKEMISEN KEINOT TYÖPAIKALLA & SUOMI & $\begin{array}{l}\text { MUUT } \\
\text { MAAT }\end{array}$ & KAIKKI & $\begin{array}{l}\text { TILASTOLLINEN } \\
\text { MERKITSEVYYS }\end{array}$ \\
\hline Jakamalla työtehtäviä työntekijöiden omien vahvuuksien mukaan & 31 & 14 & 25 & $\mathrm{p} \leftarrow .001$ \\
\hline Sopimalla, että työtoveri voi auttaa hankalissa työvaiheissa & 27 & 10 & 21 & $\mathrm{p} \leftarrow .001$ \\
\hline Huolellisella perehdytyksellä ja ohjeistuksella & 27 & 5 & 18 & $\mathrm{p} \leftarrow .001$ \\
\hline Tarjoamalla työtä helpottavia apuvälineitä & 8 & 19 & 12 & $\mathrm{p} \leftarrow .001$ \\
\hline Antamalla lisää aikaa työtehtävien tekemiseen & 14 & 9 & 12 & ns. \\
\hline Antamalla tietoa oppimisvaikeuksista (esim. esitteinä) & 3 & 9 & 5 & $p<.001$ \\
\hline Järjestämällä rauhallinen työtila & 4 & 3 & 3 & ns. \\
\hline Muulla tavoin & 2 & 3 & 2 & ns. \\
\hline
\end{tabular}

Taulukko 2. Luottamusmiesten, työsuojeluvaltuutettujen ja työnantajan edustajien käsitykset siitä, miten työpaikalla on tuettu työntekijää oppimisvaikeuksissa Suomessa ja muissa maissa (niiden osuus, joiden mielestä väittämä kuvaa oman työpaikan tilannetta) \%.

Lähde: Puumalainen ym. 2015. 
nen henkilö aikuisten ohjaamisessa tutkimuksiin. (Korkeamäki, Haarni \& Seppälä 2010.)

Korkeamäki ja kumppanit (emt.) käyvät aiheesta mielenkiintoista keskustelua artikkelissaan Aikuisten oppimisvaikeuksien ja tarkkaavuushäiriöiden diagnosointi sosiaalisena toimintana. Psykologian tai lääketieteen alan tutkimuksiin verrattuna oppimisvaikeuksia ja tarkkaavuushäiriötä on tutkittu vähemmän yhteiskuntatieteellisestä näkökulmasta. Niin ikään yksilöiden omat kokemukset oppimisvaikeuksistaan ovat jääneet vähemmälle huomiolle. Sosiologisissa tutkimuksissa vaikeuksien diagnosointiin suhtaudutaan yleensä kriittisesti yksilön elämään tunkeutuvana medikalisoitumisena. Toisaalta kuitenkin monet kärsivät oppimisvaikeuksista ilman, että osaavat tunnistaa monenlaista ahdistusta aiheuttavaa syytä "hitautensa" tai "muistamattomuutensa" taustalla.

Tutkimuksissa ihmiset ovat kuvanneet tunteneensa helpotusta, kun epämääräiselle asialle on annettu nimi. Useinhan myös sairauksien kohdalla diagnoosin saaneet kertovat helpotuksen tunteistaan saatuaan lääketieteellisen ratkaisun pitkään jatkuneisiin määrittelemättömiin oireisiin. Oppimisvaikeus- ja tarkkaavuushäiriöihin saadun diagnoosin merkitystä voidaan katsoa myös siltä kannalta, että se erottelee fysiologiset syyt moraalisista, erityisesti tyhmyydestä ja laiskuudesta. Diagnoosin saamisen on havaittu myös aktivoivan monia oman elämäntarinan uudelleenarvioimiseen. Korkeamäen ym. haastattelemat ihmiset antoivat aikaisemmille kokemuksilleen uusia tulkintoja ja arvioivat myöhäisen diagnoosin seurauksia. He esimerkiksi ilmaisivat pettymystään aiempien mahdollisuuksien menettämisestä, kun oppimisvaikeutta tai tarkkaavuushäiriötä ei ole tunnistettu lapsena vaan vasta aikuisena. Haastatellut tiedostivat hyvin, miten oppimisvaikeus oli vaikuttanut omiin koulutusvalintoihin ja opintojen sujumiseen. Tutkimus paljastaa myös sen, kuinka diagnosoidut voivat itse käyttää diagnoosia vaikeuksien legitimisoinnissa ja siten myös yhteiskunnallisten käytäntöjen kritisoimises-

\section{LUKIVAIKEUDEN ILMENEMINEN}

Lukeminen, luetun ymmärtäminen ja äänteet

- lukeminen hidasta

- ääneen lukeminen ikävää

- Lukiessa rivit "hyppivät silmissä"

- luetusta "ei jää mitään päähän"

- $\quad$ kirjaimet sekoittuvat keskenään

\section{Kirjoittaminen}

- kirjoitusvirheet yleisiä

- tekstin tuottaminen työlästä ja/tai hidasta

- $\quad$ kirjaimet sekoittuvat, niitä puuttuu tai ne vaihtavat paikkaa, esim. b ja d, $p$ ja $b, k$ vai $k k$

\section{Matematiikka ja numerot}

- matematiikka hankalaa

- numerot vaihtavat paikkaa: 59 vai 95

- kertotaulu ei automatisoidu

- numerosarjat hankalia

\section{Kielet}

- $\quad$ vieraat kielet vaikeita: "ei kielipäätä"

\section{Ulkoa opeteltavat asiat}

- asioiden ulkoa opettelu vaikeaa

- aakkosjärjestyksen muistaminen hankalaa

\section{Suunnat, aika}

- $\quad$ oikea/vasen ja itä/länsi sekoittuvat keskenään

- $\quad$ karttaa vaikea käyttää

- $\quad$ vaikea pysyä aikatauluissa

- $\quad$ vaikea oppia kellonaikoja

\section{Keskittyminen}

- keskittyminen häiriintyy helpost

- $\quad$ hitaus tai hätäisyys tekemisessä

\section{Motoriikka}

- lukivaikeuteen voi liittyä motorista kömpelyyttä

(Lähde: Erilaisten oppijoiden liitto ry) 
sa. He kokevat, että elämä olisi ollut helpompaa, jos oppimisvaikeudet olisi havaittu aiemmin ja niihin olisi saanut asianmukaista tukea. Korkeamäki ym. painottavat, että yksilölle itselleen kyse ei ole pelkästään diagnoosista, vaan avun, tuen ja ymmärryksen saamisesta yleisemminkin.

Vaikka oppimisvaikeuksiin yhdistetään lukuisia stereotyyppisiä käsityksiä, oppimisvaikeudet ja tarkkaavuushäiriö ovat monia psykiatrisia diagnooseja neutraalimpia, mikä saattaa helpottaa niiden esille tuomista. Mitä arkipäiväisempiä ja puhutumpia oppimisvaikeudet ovat, sitä vähemmän niihin liittyy leimaavaa vaikusta. Tässä mielessä diagnooseilla voi olla myös positiivista vaikutusta erilaisuuden näkyväksi tekemisessä. Yleistyvän diganosoinnin yhtenä funktiona on selittää, miksi tietynlaista käyttäytymistä ei tulisi tuomita vallitsevien kulttuuristen normien mukaisesti. Diagnosoiminen ei merkitse yksinomaan toimijuuden alistamista. Se voi myös antaa yksilölle uusia mahdollisuuksia rakentaa omaa identiteettiä. Tietoisuus omista oppimisvaikeuksista lisää itseymmärrystä, tukee itsetuntoa, auttaa hakemaan tukea oppimisvalmiuksien vahvistamiseen ja kehittämään itselle sopivia kompensointikeinoja. Yksilöä itseään diagnoosi helpottaa selittämään menneitä elämänvaiheita ja kokemuksia. Se voi tarjota resursseja ja vahvistaa mahdollisuutta säädellä tietoa omasta erilaisuudesta. Diagnoosi voi avata uuden tarkastelukulman esimerkiksi omiin koulukokemuksiin, ja kyseenalaistamaan koulujen käytäntöjä, jotka suosimalla "normaaliutta" samalla tulevat sortaneeksi erilaisuutta. (Korkeamäki, Haarni \& Seppälä 2010.)

Heikki Silvennoinen

kasvatustieteen professori

Turun yliopisto

\section{LÄHTEET}

Gerber, P.J., Schneiders, C.A., Paradise, L.V., Reiff, H.B., Ginsberg, R., \& Popp, P.A. (1990). Persisting problems of adults with learning disabilities: Selfreported comparisons form their school-age and adult years. Journal of Learning Disabilities, 23, 570-573.

Korkeamäki, J. (2010). Aikuisten oppimisvaikeudet. Näkökulmia selviytymiseen. Kuntoutussäätiön tutkimuksia 83/2010. Helsinki: Kuntoutussäätiö.

Korkeamäki; J. (2011). Myös aikuiset tarvitsevat tukea oppimisvaikeuksiin. Aikuiskasvatus 31 (2), 128-135.

Korkeamäki, J., Haarni, I. \& Seppälä, U. (2010). Aikuisten oppimisvaikeuksien ja tarkkaavuushäiriöiden diagnosointi sosiaalisena toimintana. Sosiaalilääketieteellinen aikakauslehti 47 (1), 109-122.

Korkeamäki, J., Reuter, A. \& Haapasalo, S. (2010). Aikuisten oppimisvaikeuksien tunnistus, arviointi ja kuntoutus. Opi oppimaan -projektin toimeenpano ja tulokset. Työselosteita 40/2010. Helsinki: Kuntoutussäätiö.

Linnakylä, P., Malin, A., Blomqvist, I. \& Sulkunen, S. (2000). Lukutaito työssä ja arjessa. Aikuisten kansainvälinen lukutaitotutkimus Suomessa. Koulutuksen tutkimuslaitos. Jyväskylän yliopisto.

Malin, A. (2006). Suomessakin on heikkoja lukijoita. Teoksessa Leskelä L \& Virtanen H (toim.) Toisin sanoen. Selkokielen teoriaa ja käytäntöä. Helsinki: Kehitysvammaliitto, 15-31.

Malin, A., Sulkunen, S. \& Laine, K. (2013). PIAAC 2012: kansainvälisen aikuistutkimuksen ensituloksia. Opetus- ja kulttuuriministeriön julkaisuja 2013:19. Helsinki: OKM.

OECD (2013). OECD Skills Outlook 2013: First Results from the Survey of Adult Skills. Paris: OECD Publishing.

Puumalainen, J., Laisola-Nuotio, A. \& AlaKauhaluoma, M. (2015). Oppimisvaikeudet työpaikoilla. Raportti kartoituksesta ja sen tuloksista. Helsinki: Työväen sivistysliitto.

Reiterä-Paajanen, U. \& Haapasalo, S. (2010). Oppimisvalmennus aikuisten oppimisvaikeuksien kuntoutusmuotona. Helsinki: Kuntoutussäätiö.

Taymans, J., Swanson, H. L., Schwarz, R., Gregg, N., Hock, M. \& Gerber, P. (2009). Learning to Achieve: A Review of the Research Literature on Serving Adults with Learning Disabilities. Washington: National Institute for Literacy. 